\title{
AUGMENTED REALITY AS A MEDIUM OF GAMIFICATION OF CONSUMPTION IN THE CONTEXT OF GLOBAL VILLAGE
}

\author{
Deniz YENGIN \\ İstanbul Aydın University, Turkey \\ denizyengin@aydin.edu.tr \\ https://orcid.org/0000-0002-6846-0770 \\ Tamer BAYRAK \\ İstanbul Aydın University, Turkey \\ tbayrak@aydin.edu.tr \\ https://orcid.org/0000-0003-0776-1606 \\ Özge TOPÇU \\ İstanbul Aydın University, Turkey \\ https://orcid.org/0000-0003-3729-7509 \\ ozgeeetopcu@hotmail.com \\ Berkan BAYINDIR \\ İstanbul Aydın University, Turkey \\ https://orcid.org/0000-0001-7629-3928 \\ berkanbayindir@mynet.com
}

\begin{abstract}
In today's world the differences between the virtual and real have fairly diminished. In this context, the virtual reality systems, which are the new means of communication and have the characteristic qualifications of new media technologies, have changed the one way communication model of traditional media. As a result of this transformation of the communication model, the user has begun to interact with the content producers. Therefore, the user is transformed from the passive role to the active role and continues his/her life in a two-way communication model. In this way, virtual environments, which the so called new media technology devices has brought in, made it possible for the users to control and interact with interfaces and this made it easy to send the message from the source to the target. The communication notion stands in the basis of the technology, which is produced for consuming; also it forms a basis for new media technologies like virtual reality. Especially gamification of consumption and by this way increasing the consuming behavior, this technology is the frontier of continuously improving new media technologies. In this context, in this study Huizinga's game notion is related with augmented technology and IKEA's augmented technology is examined.
\end{abstract}

Keywords: New Media, Augmented, Consumption, Virtual Environment

\section{GLOBAL KÖY BAĞLAMINDA TÜKETIMIN OYUNLAŞTIRILMASI ARACI OLARAK ARTIRILMIŞ GERÇEKLIK}

ÖZ

Günümüz dünyasında sanal ile gerçek arasındaki farklar oldukça azalmıştır. Bu anlamda yeni bir iletişim kanalı olan ve yeni medya teknolojilerinin karakteristik özelliklerini yansıtan sanal gerçeklik 
sistemleri, kullanıcının geleneksel medya ile sahip olduğu tek yönlü iletişim modelinin dönüşmesine neden olmuştur. Dönüşen iletişim modeli kullanıcı ile içerik üreticilerinin etkileşime geçmesi sonucunu doğurmuştur. Böylelikle kullanıcı birey pasif rolden aktif role taşınmakta ve çift yönlü iletişim modeline sahip olarak yaşamına devam etmektedir. Bu sayede yeni medya teknolojileri olarak adlandırılan araçların ortaya çıkardığı sanal ortamlar, kullanıcıların denetimini ve etkileşimini mümkün kılan ara yüzlere sahip olmuş, iletinin kaynaktan hedefe iletimini oldukça kolaylaştırmıştır. İnsanın tüketim adına ürettiği teknolojinin temelinde yatan iletişim kavramı, artırılmış gerçeklik gibi yeni medya teknolojilerine de zemin oluşturmaktadır. Özellikle tüketimin oyunlaştırılması ve böylelikle tüketimin teşviki gibi girişimlere ön ayak olan bu teknoloji ile yeni medya teknolojilerinin gelişiminin sürekliliği gözler önüne serilmektedir. Bu anlamda çalışmada Huizinga'nın ortaya koyduğu oyun kavramıla artırılmış gerçeklik teknolojisi ilişkilendirilmiş, Ikea'nın kullanıcılarına sunduğu artırılmış gerçeklik teknolojisi incelenmiştir.

Anahtar Kelimeler: Yeni Medya, Artırılmış Gerçeklik, Tüketim, Sanal Ortam

\section{INTRODUCTION}

In today's world where the differences between virtual and real are gradually decreasing and the daily lives are transforming to virtual lives; virtual reality systems, which are the new communication channels and have the characteristic qualifications of the new communication environment, are taking the user from the passive role to the active role. The users' control and interaction on virtual environment communications are increasing and the users are becoming part of the experience via interfaces created or designed for digital systems. According to these definitions communication means the transmission of the message, which is generated with codes, from the source to the target; it is the transfer of all kinds of data from the source to the target via a channel. Social sciences are interested in people and society. Communication is one of the important branches of social sciences. With their physical and social beings, humans communicate constantly and uninterruptedly. The usage of communication in this process led to the formation of theories. İran Erdoğan explains the theory in this context as follows:

"Efforts in understanding human, society and communication, there are different approaches in any research question such as, (a) the question and the problem itself, (b) choosing it as a problem, (c) how it is going to be examined, (d) interpretation. These forms of approaches, in their broadest sense, are called theories."

If technology, which is one of the important factors in reducing the difference between virtual and reality, is examined etymologically; it is identified by the combination of Greek words techner and logos. Techner; means making and logos means knowing. Technology means "using information systematically in the processes of the industrial applications". The technological tools of the period, papyrus, parchment and paper, providing the history of the past to our time, ensured the rapid growth of technology. Harold Innis, who is a researcher on the concept, claims that the most important reason for the development of communication networks is the spreading of the writing through the printing press and electronic resources. The process of transferring information which has started with manuscript found the format with visual codes through the development of the alphabet; has brought in a uniform, repeatable, reproducible cultural reality. In his work, 'The Bias of Communication', he explains how the new technology 'scrambles' with the traditional knowledge monopoly and reveals a new monopoly of knowledge ruled by another group. Innis tried to show that communication technologies influence and shape the forms of society.

Mass media devices which are important representatives of communication technologies; affects people's world conception, attitudes and behaviors by this way new role models are created. Our senses cannot catch up with the speed of television. In fact it is known that violence has been perceived by the society as a phenomenon which is not found strange in everyday life, and this behavior affects attitudes. Gerbner has also achieved similar results in his researches. According to Gerbner, such broadcasts legitimate violence and being victims of violence. 


\section{GLOBAL VILLAGE}

Global village, which is first mentioned in McLuhan's book 'Understanding the Media' in 1964, emerges as a term describing the change and development of radio, television, and cinema as a result of an irreversible cultural extension. People can easily learn every issue around the world whenever and wherever they want. McLuhan was influential in designing the academic agenda of communication studies with the ideas he claimed. Being a popular name of the 1960s, his ideas were first appreciated in the media community and then in the 1980s they were appreciated by the academic community. Furthermore, the increase in the number of academics who use McLuhan's approaches to explain both social and cultural relations is dramatic. In this context the global village concept which was created in the 1960s is used to explain the usage of mass media devices would spread rapidly throughout the society and would actually transform the world into a global village.

McLuhan claims the communication environment as the message itself, and indicates that the basis of the communication process is the communication environment in which the message is structured. From the beginning of the late 1980s with the gradually rising globalization debates, according to McLuhan, the electronic era leads man to return to his essence and has a special importance with the technological codes it contains (McLuhan, 1964:23).

When we look at the close and distant past of the world of communication, we encounter three revolutions. The Chirographic revolution (the invention of writing in the 4th century B.C.), the Gutenberg revolution (the process that follows the invention of the printing press in the mid-15th century) and finally the electricity and electronic revolution (the period when telegraph was invented and followed by the invention of radio and television). In addition, we are confronted with four different cultures which follow each other under the influence of the communication tools being used: oral culture (transfers the information via speech); written culture (uses the written language); typography culture (transfers the information via printed book) finally electrical and electronic media culture (faster transfer of information via tools such as TV and radio). The decisive feature of this revolution is; information has been distributed more quickly and more rapidly (Baldini, 2000: 5). Including McLuhan, thinkers who are concerned with communication problems think that the media in which people are communicating directly or indirectly affect the society they live in. Referring to the possibilities created by electronic communication technologies, McLuhan believes that the subject (individual or mass communication media) in communication comes before the object. According to McLuhan, medium is the message, and it is the transform of the speed and the measurement. He brings in change to relations between human beings.

According to McLuhan, oral tradition and electronic media are merging into a new formation. Especially in this sense, with the development of the internet and social networks, it is possible that anything can be there at whenever it is desired and in many places. Like a topic written on social networking sites can reach many places at the same time, people are now consuming the same brands and it shows the importance of the concept of "global village" proposed by McLuhan in our time. The world has become a big village where people learn everything at the same time and can access the information they want whenever and wherever they like. The internet has a very important place in understanding of communication process which started with people and continues its development with the new communication environment. Along with technological developments, communication tools are also changing. Especially the media phenomenon has experienced a great transformation after the internet. In the process of mass communication, the medium used for transferring the message is defined as media (Yengin, 2017: 83).

The human being who lives a life engaged with the media phenomenon and is transformed by the technology is also embroidered in McLuhan's Mechanic Bride. With this study, which is the precursor of mechanized understandings improved with technological innovations, which are transformed from new communication environments, the traditional percipience of violence changes its form and confronts us as "Mechanical Violence". When mechanical violence is examined with a perception that it is differentiated with informatics, it brings out the title 'new'. In the Global Village book, McLuhan 
states that television will transform the world into a global village by gathering the world under a single nation. McLuhan states that the biggest social impact of the phone is to destroy the caller's identity. He also explains the Global Village approach based on this understanding. "In reality, if an organization becomes the largest economic group of the nation, it is then the social structure" in these words, the perception of technological determinism will transform the society into a small village with information bombs. (McLuhan, 2001: 201). This transformation will clear off people's old private identities and they will be identified as new identities in a social structure as part of technology. The technological determinism approach emphasizes that human does not determine his/her own destiny but the technology which is an extension of him/her does it. McLuhan focuses on the communication devices shaping the world and directs the masses as a result, a single mass formation emerges.

\section{CONSUMPTION AS A GAME}

People's close relationship with technology is evaluated in different ways by some thinkers. One of the most striking approaches is that man is processing the information he has acquired via dramatization. The root of the word Ludoloji which means "game science" is ludik in Latin and it means 'not serious'. According to Aristotle game exists to spend leisure time usefully and harmlessly. Also, he argues that game is a kind of relaxation state and mind relief action. Huizinga emphasizes game as "activities made willingly and regularly in a specific time and space". It shows us that over the time game notion turned into "a vital activity" in a social and individual sense from being "an unnecessary activity".

Huizinga describes game as "an absorbing thing which is unreal" but "at the same time swallowing up the players deadly into itself from head to toe" "while working freedom continues consciously outside", while the "accustomed life" in other words the existing life continues as it is. It is an activity which is free from any material advantage and with no earnings. Game has distinctive place and time limits and it is an activity with a regular style which has unchanging specific rules within these limits.

Roger Caillois describes game as "a falsely believed doubtful, unproductive and controlled by rules activity which is composed by free sections". According to Bernard Suits, playing game is being guided in an activity, in a story, complying with only permitted rules which are more effective in advantage of losing, accepted rules are only to make that activity possible. Brian Avedon and Sutton identifies game as "a voluntary controlling system after its simplest level and the contradiction between powers, an imbalance limited by rules in order to have the rules". Katie Salen and Eric Zimmerman defined game as "an activity which ends up with a numerical result in which the players, who are determinate by the rules, are in an artificial conflict. According to Jesper Juul game is " $a$ transferable activity which has changeable and numerical results formed by rules, in which different results nominated with different values, the player, who is focused on the result in an emotional context, makes an effort to affect the result".

Game is something that is aimed or not aimed for a purpose, can be executed with rules or without rules but in any case child takes place in willingly and likely, a part of real life and the best learning process for a child being the basis of child's physical, cognitive, lingual, emotional and social development. Game is an enjoyable and optional activity which is usually outside of the real world having uncertain, specific rules and culture. According to Aristotle, game exists for spending free time in a useful and harmless way. He argues that game is a kind of act for "relaxation" and "preoccupation". Huizinga describes game as "activities made willingly and regularly in a specific time and space". Important qualities arise in the context of these definitions. These qualities are; limitedness, regularity and non-serious. In this context, game is a notion which has rules, is not serious; has entry and exit limits, is not real but involves individuals into the activity by giving the feeling as if it is real. In the context of this definition game observation is done. In conclusion, game is a free action, it stays outside of daily life on purpose, although it is not considered as a serious thing, player focuses himself intensely and completely into it. A financial gain, profit or benefit is not expected from the act. Occurrence of it is within its time and place limits, determined rules and order. Huizinga states that there are limits in a game; in this context he specifies that it has a 'Magical Circle'. The Magical Circle means a limited circle in which one can enter or exit the game, a world is 
represented in the Magical Circle which the rules related with the game are stored and has consequences. Huizinga, who studies on game, explains the magical circle as follows;

"All game movements are determined in advance intentionally or naturally within its limits materially or ideally. Arena, kart painting, magical circle, temple, scene, curtain, tennis court, trial. There is all form and function on game ground, forbidden sports, isolated circle, blessedness are gained via special rules. All of them are ordinary worlds in this temporary world; they are dedicated to action which relies on the performance."

According to this theory each game has a magic circle. In order to start game players have to enter and exit this invisible featured Magic Circle. In this circle in accordance with defined or known rules game play takes place. Wrestling and Japanese Sumo Wrestling are examples that can be given to the concept of magic circle.

Game at the same time is a turning point that triggers "Creativity Courage" which human has as a hidden power and it improves-makes him/her perfect. Via this released courage of creation, humans expose their feelings, thoughts, and fantasies with the coordination of "Body, Language, and Brain". By doing so human creates an original motion field for him/her and exists (Uçak, 2015: 103).

Roger Caillois explains game as; freely play, personal, not serious, unproductive, and believed to be real. He also states the features of game as follows; freelance, isolated in the sense of time and space, managed by rules, not based on production, and artificial. Paidia is emphasized as uncontrollable fantasy, and ludus is emphasized as win and lose situation. Game defined as an activity; must be free, surrounded by not serious rules and considered as if it is real. Caillois has classified the game with Huizinga's game items. This examines classification in two dimensions.

The assumptions in Huizinga's Homo Ludens and Caillois' Man, Play and Games converge to the idea that games are "unproductive". According to Caillois game is; freely accepted, but continues in certain time and place according to the restrictive rules, includes feelings of tension and entertainment, and it is a voluntary act or activity with awareness of that it is different from real life. The game is different from work. Work and game requires more social control. Convergent selectivity becomes the issue as work and game are usually subjects to social control. Work and game are subject to social control with the belief systems in them. This secret individuality, childish reflection and premature internalizations are primary group situations. Public opinion is subject to social control; advertising, theater, art, etc. require convergent selectivity. The person shows himself/herself in different social control and convergent selectivity conditions. The characteristic of the work is restricted as pain, convergent selectivity, conditional communication, and pleasure. Ordinary life is impossible without communication, in school, in church, at work, on farm; all in all, communication is in everywhere. The role of communication is a must of living in society. The culture occurs in the game and the game faces with social control and convergent selectivity takes its place. Mainly fantasy is not in the form of escaping from reality, backing up, yearning, neurotic, or else. The principled communication notion's being closer to the pleasure issue is as important as symbolic representation.

\section{GAMIFICATION THE TECHNOLOGY}

New media technologies develop more rapidly than traditional media in accordance with consumer's demand. Development of these technologies is directly relevant to presenting practical data of technical information. Virtual reality technology draws attention as an important feature of new media technologies. Morton Heilig invented the first virtual reality simulator called "Sensorama Simulator" for virtual reality, which is rapidly developing as a result of consumer's demand. Heilig's this invention consists of two $35 \mathrm{~mm}$ camera displays, sound, scent, a ventilator placed near viewer's head and a vibrating chair. In this system, scent and air is given to user's face with the help of a ventilator. While perceptual reality is being formed in an armchair on the other hand hyper-real setting is formed with the scene that is being watched, by doing so perceptual reality notion is improved. 
In a way that supports Heilig's work Stherland, in 1966 developed a device called "Sword of Damocles". The device containing a cathode ray tube is a kind of image headgear. With the device which Stherland has developed, he discovered that hyper-real perception can be supported with the computer generated images even though they are not real images. In this period, Myron Kreuger also developed Videoplace via a projection device and took the virtual reality technology to higher levels. Virtual reality technology is a full-fledged environment glasses which users place on their heads. Because these glasses require a high framing speed, they need to work compatible with powerful computer hardware. These requirements which cause the device and the computer work with expensive hardware, also limit the number of users. Another major disadvantage of virtual reality glasses which works with computers is the intense cable clutter. This feature, which challenges the users, forced the manufacturers of virtual reality glasses search different solutions. The augmented reality glasses that are emerged in this sense are a breakthrough product which eliminates all the negativities experienced by the users. These glasses, which have a structure different from that of virtual reality glasses, have a kind of computer in them and therefore the need for external computer hardware has been eliminated. The augmented reality glasses, which are free from cable clutter and computer necessity, also eliminate the digital illnesses and usage limitations caused by virtual reality glasses and created a new communication environment in which virtual and reality objects interact.

The augmented reality technology can be used both with glasses and smart phones. With the technology which has a lot of examples, users can place virtual objects to their photos or videos which they shoot with cameras of their smart phones. With these programs, which use a kind of artificial intelligence, beforehand designed virtual objects can be placed in the images. The virtual objects placed in the images interact with the real objects and take the users to a different communication environment. These programs, with which users can design their living environments without any efforts, are also used as important communication devices for the big companies to reach their customers. This technology, which is also used for entertaining, keeps improving continuously.

\section{Microsoft HoloLens}

HoloLens, which is an augmented reality glasses, was introduced by Microsoft, at first it was introduced as project Baraboo. The glasses, which has windows 10 operating system embedded, was up for preorder sale globally by Microsoft on October 12, 2016. With an adjustable padded inner band, Hololens has the ability to be tilted forward, backward, upwards and downwards thanks to the band. The device with camera and sensor in the front part has head-up lenses with transparent combiner. The glasses which can be adjusted according to the distance between the eyes, has a pair of 3D audio speakers corresponding to the user's ear. This system, which differs from standard sound systems, accelerates and strengthens the user's virtual-realism compatibility.

HoloLens has an accelerometer, gyroscope, magnetometer and four media detection sensors. The glasses which has a $120^{\circ}$ to $120^{\circ}$ sight angle also includes an energy-saving field imaging camera, 2.4 megapixel photo camera, video camera, four microphone arrays and one ambient light sensor. With all these features, the glasses can perform tasks such as spatial mapping, gesture recognition, and voice recognition. The lenses placed in the glasses work like a separate screen for each eye. The 'light engine' lens, which are located on the lenses, reflects light and wave, and the processed image is perceived and processed by the user. With an average duration of 2-3 hours of active usage and two weeks of standby time, the embedded rechargeable battery supports the user based utilization of the glasses. 


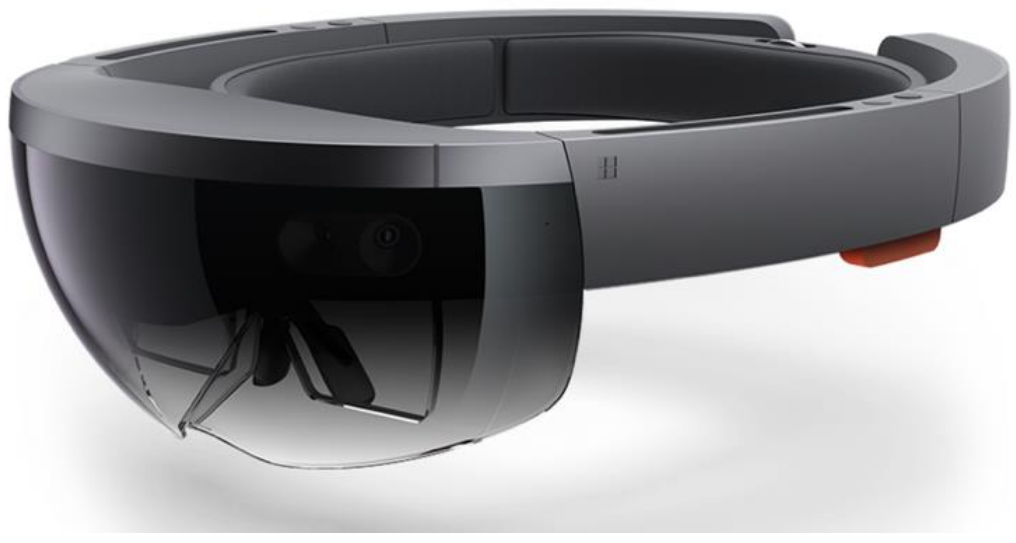

Picture 1. Hololens

Reference: https://www.windowscentral.com/microsoft-hololens

HoloLens is designed for using emotional and natural interface commands. The glasses which are sensitive to such factors like gesture and sound work to maximize the interaction between the user and the device. The glasses can also work compatible with devices such as computers and phones. In this sense the interaction between the HoloLens and the user is quite dynamic and continues with highly data transfer.

\section{Google Glass}

Google Glass, announced by Google Company, offers a voice command system, navigation, photo/video and web browsing features. The glasses, which are supposed to have a voice command system, also have an extended digital library. Google Company has previously announced that each new generation of glasses different features will be added and with the headphones which are designed for the glasses user's demands will be satisfied. A deal was signed with music producer Young Guru for the glasses which was announced with a highly effective advertising campaign, and the features of Google Glass introduced through the internet and traditional media.

Designed to be a personal eyeglass assistant, Google Glass has an Android 4.0.4 operating system. In this sense, the glasses have the ability to process commands like a smart phone. This will cause an effect like using a Smartphone without using the hands.

According to the information that Google shared, the glasses will be made with mixture of aluminum and fiber parts so that it will be very flexible, and this feature will be more developed in each generation. From this point of view, the first generation of Google Glass is not very different from regular glasses. With the new generation of glasses, the company also aims to appeal to the visual taste of the user with five color options.

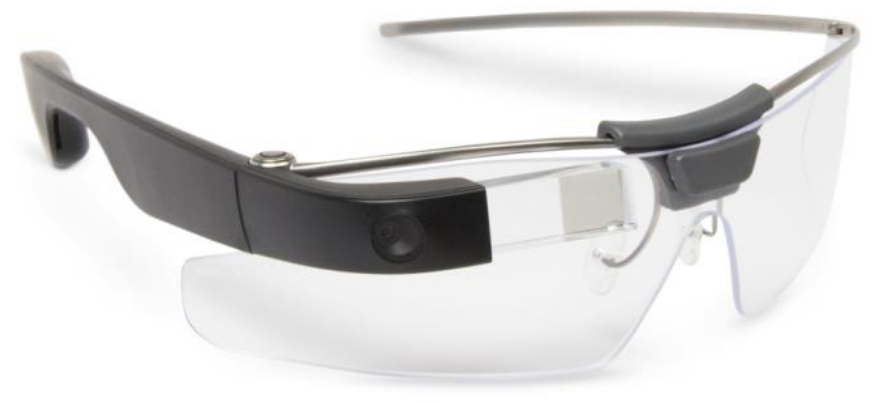

Picture 2. Google Glass Reference: goo.gl/2pVBLW 
The glasses, which can record 720p HD quality video, can also detect location with GPS and with the help of GPS it can be used as a navigation device. These glasses can be connected to the Smart phones with WIFI and Bluetooth features which allows users to use different devices indirectly and thus reduce the need for different devices. Having 16 GB of memory, these glasses have a fast communication power by the help of $682 \mathrm{MB}$ Ram.

\section{METODOLOGY}

Science is systematic knowledge. Different events, situations, and movements occur around our environment. It is absolutely necessary to scan systematic data in order to examine and interpret this disorganized structure. As a result of this systematic scanning of the data, the concept of knowledge emerges. Therefore, systematically analyzed data is called as "systematic knowledge", "science". Science is; to produce information, to do research, test, and confirm knowledge. It is seen that the knowledge has been constantly renewed and tested at the point where it stands today. As a result of these researches and tests we produce new information. This endless situation is constantly updating itself. This updating occurs thanks to science with knowledge which is objectively doubtful. We are trying to reach the unknown knowledge as new information with the known one. In order to get this knowledge it is necessary to follow the methods of science which has a systematic structure and approach. Research is conducted with the "unknown knowledge research process" in order to follow the methods of science. New information is being produced from the knowledge which has been gathered with the help of studies done up to now. The human being who lives in society is doing a search constantly. Rapid developments in communication technologies also bring new dimensions to institutionalization of the system with new environments and new possibilities. With this process; nowadays the individual is not an object in the process of mass communication and becomes a participant subject of the process. The features brought by the technology at the same time bring new problems as well. What is important here is to be able to produce theoretical solutions to these problems (Yengin, 2017: 28).

Technique is the knowledge of production, gaining something. Technology, on the other hand, is the socialization of this knowledge, having social reflections and having a social meaning. Whenever a new thing is produced or presented to the society, it is usually called as a new technology. Technology presented to the usage of individuals and society; is now being renewed more rapidly. Especially with scientific studies technological products and their usages are increasing. Changes and updates in technology have also improved the ways of transmitting information to the individual and society. Technology forms of communication environments can be constantly renewed. This change brings together different variables. These variables may sometimes have positive qualifications and sometimes may have negative qualifications. These variables are examined by Walter Ong, Harold Innis and Marshall McLuhan and technologically related approaches are put forward (Yengin, 2014: 49). In this study, with content analyze method, IKEA application is chosen as a sample and the products which are presented to the users via augmented technology are being analyzed.

Content analyze is not an observation method moreover it is a sort out method and instead of observing and asking questions, the researcher prepares a content by taking perceptible communication materials into consideration. In this context, with content analyze the hidden data in the communication material is revealed. For this reason written materials are used predominantly as an examination unit. Written texts constitute a whole. Individuals who read and try to understand these texts, often miss small pieces. The words which make up the text provide explanatory data groups about the small parts which could have been missed out. According to this, words that are the units in which the basic meaning is coded, are revealed by content analyze and decoding can be possible by this way. It is the objective, systematic, and quantitative analyze of the message given in communication. The approach is communication is everything (Yengin, 2017:77).

Semiotics is the science of signs and the product, which is presented in the linguistic system, is the study area of this school. It examines the system of interpretation. It is thought that it is necessary to look at the underneath structure in order to understand the events and phenomena that occurs. Symbols used in social communication field are real communicative products (Güngör, 2016: 222). School of 
semiotics is the construction of indicators that produce meaning by interacting with the targets. In this school where the focus is on the message, communication products are in the center while studying the production and change of meanings (Yengin, 2017:82).

Roland Barthes has developed a systematic model in which meaning is analyzed and it is based on interaction. In this Barthes' approach; interpretation is in the center and the interpretation consists of two levels. They are denotation and connotation.

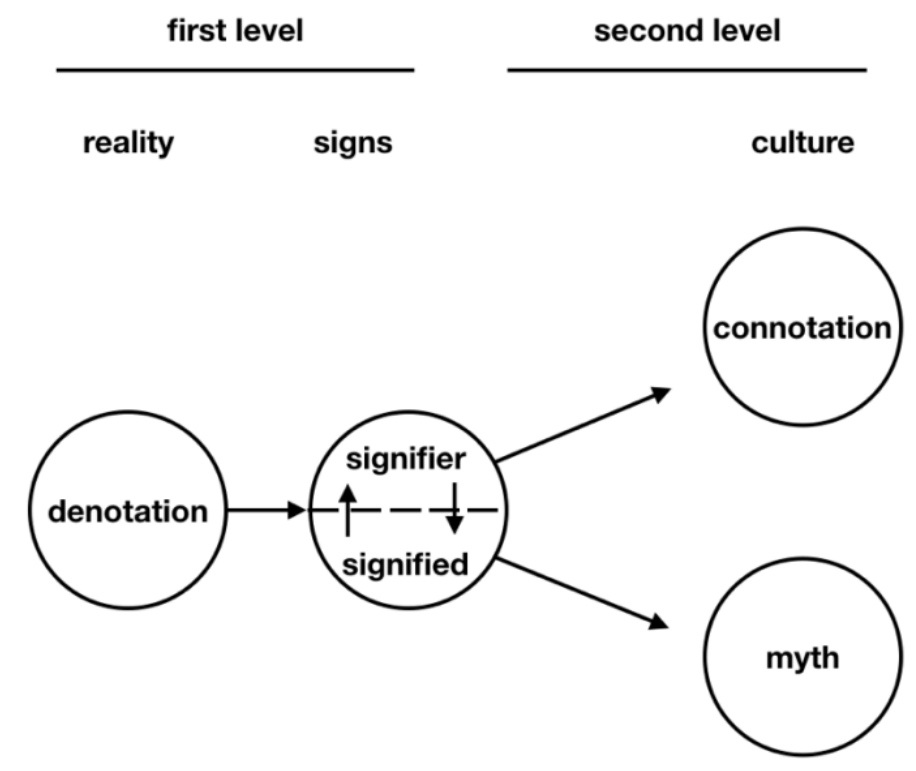

Figure 1. Barthes' Binary Interpretation Process

Reference: Fiske, 2014: 186

Denotation is the first level of meaning. Denotation; signifies the meaning of semiotic, it is the meaning in the sign and the relation between the Signifier and the signified. For example; with the visual image of the toy in a child's mind that sees a toy, the concept of the toy comes to his/her mind. According to Barthes, Connotation is the second interpretation level. Connotation is the interaction time when the sign combines with the user's intellectual level. The connotation emerges when it meets with the user's emotions and cultural values According to Fiske denotation is what is photographed and connotation is how it is photographed (Fiske, 2014: 13). This study is analyzed in the context of Roland Barthes' binary (denotation and connotation) interpretation approach.

Table 1. From Denotation to Connocation In The Dock Sign

\begin{tabular}{|l|l|l|}
\hline Denotation & {$[\mathrm{d}][\mathrm{o}][\mathrm{c}][\mathrm{k}]$} & Signifier (1) \\
\hline Connotation & dock- Sea meeting with land & Signified (2) \\
\hline & Intersection of two opposite things & Signified (1) \\
\hline Virtual meaning & Intersection of life with death & Signifier (2) \\
\hline & Digitally coded image & Signifier (1) \\
\hline & $\begin{array}{l}\text { Locating the digitally processed image } \\
\text { into the real environment }\end{array}$ & Signified (2) \\
\hline
\end{tabular}

\section{FINDINGS}

The concept of augmented reality, which was named by Ronald Azuma for the first time, has been using in man y areas such as communication, healthcare, architecture and automotive. Until 1999, the concept of augmented reality generally had been seen as a field of research by scientists, has now begun to be seen on consumer based products. At first, because of the devices that are produced for augment reality were expensive, heavy and complicated, they could not reach the consumer directly. After an intense improvement process, in 2000s the game industry realized the importance of 
augmented reality. As a result, various digital games were produced in the same period and delivered to a lot of users. After 2009, the augmented reality, which has gained support from libraries and hardware devices, was begun to be mentioned about (Köymen, 2014: 17). Roland Azuma has mentioned three important features about this technology. The first one of these features is the combination of virtual and real objects in a real frame, secondly real-time interaction and finally the harmony of real objects and the virtual objects (Özgan, 2012: 13).

Sharing which is enabled with interaction and every kind of organization is instantly communicating means the social media (Akyaz1, 2017: 1496). In this context, being instant is experienced as time and space awareness with the developing technologies. Being free from time and space communication process improves; new platforms take place in our lives. Augmented reality systems are examples to this occasion. Augmented reality technology, which has examples in plenty of areas, is a vehicle for manufacturers to reach users. For example in furniture sector the sample applications which are found in the digital environment are important to help the customers to choose their furniture among the options. With these applications, customers can place the products they like from the catalogues in their homes as if they are real. When we look at the augmented technology which is used in the furniture sector IKEA's popular augmented technology application is remarkable. In this application called "Snapshop Showroom", IKEA digitizes 211 catalogs published every year (Y1lmaz, 2007: 64). As well as this application IKEA has also worked on an external application containing information about many products.

Initially furniture, such as a coffee table, armchair, and so on took place in the application. However, with a later update, the user can be able to add other products as well. In addition, the user can send the attached image of the furniture via sharing photograph or video to his/her friends and they can exchange ideas about the product which the user likes. Therefore, it is seen as a successful initiative thanks to its features and being first as an example. When a user decides to buy a new sofa set or other product, it is difficult to predict how the product will stand at home or whether the product will match the house or not. This application allows the consumer to shop more easily in this sense.

IKEA's application called IKEA Place is based on Apple's augmented reality platform, ARKIT. With this program, IKEA virtualizes more than 2000 products and presents them to the user. The products are three dimensional in this application, the user can choose any desired product with this application. By turning the smart phone into the desired area, the user has the chance to see the furniture as it is in the house and has detailed information about the product. In order to do this the only thing the user has to do with the application is to scan the room with the camera (https://www.log.com.tr/ikeaninartirilmis-gerceklik-uygulamasi-yayinda-video/). This application has real and scalable models of the products included in the application. The user has instant information about whether the chosen product will fit in the selected area or not. At the same time the user can take the photograph of virtual furniture which he/she located in the house and share it with his/her friends.

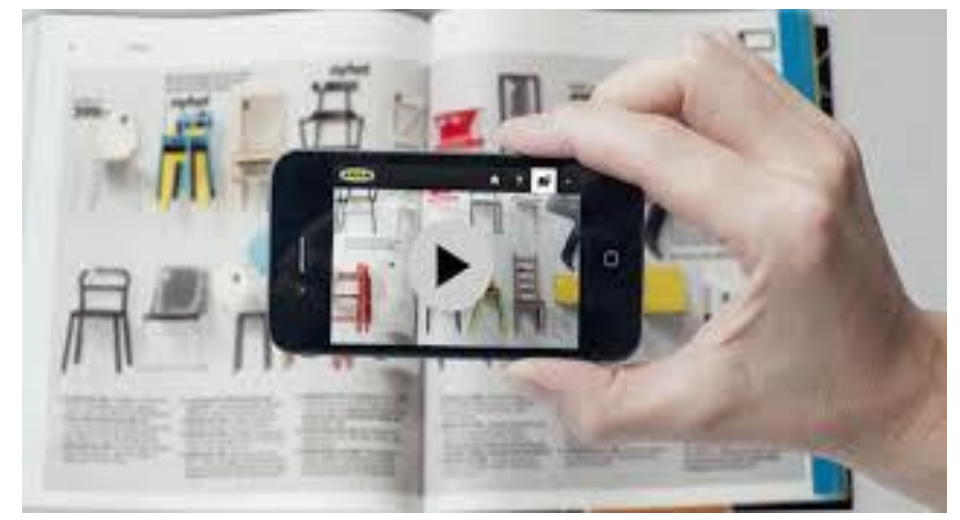

Picture 3. IKEA's Augmented Reality application

Reference: https://www.xtrlarge.com/2017/09/26/ikea-place-artirilmis-gerceklik-mobilya/

Submit Date: 11.12.2017, Acceptance Date: 25.03.2018, DOI NO: 10.7456/10802100/016

Research Article - This article was checked by Turnitin

Copyright $\odot$ The Turkish Online Journal of Design, Art and Communication 
IKEA, which first met the customers in the name of "place in your room" in 2013, aims to carry the brand to the consumer's home and ease shopping for the user with this application. From this point of view, the application has a very simple and useful interface for the user. In this continuously updated application, new items are constantly added.

The products shown in the application are identical to the products sold in the store. As it is observed from the application that IKEA also measures the demand for the future products which will be sold in the market. In this sense, with the application IKEA measures the response of the users towards the products and designs its products according to these criterions.

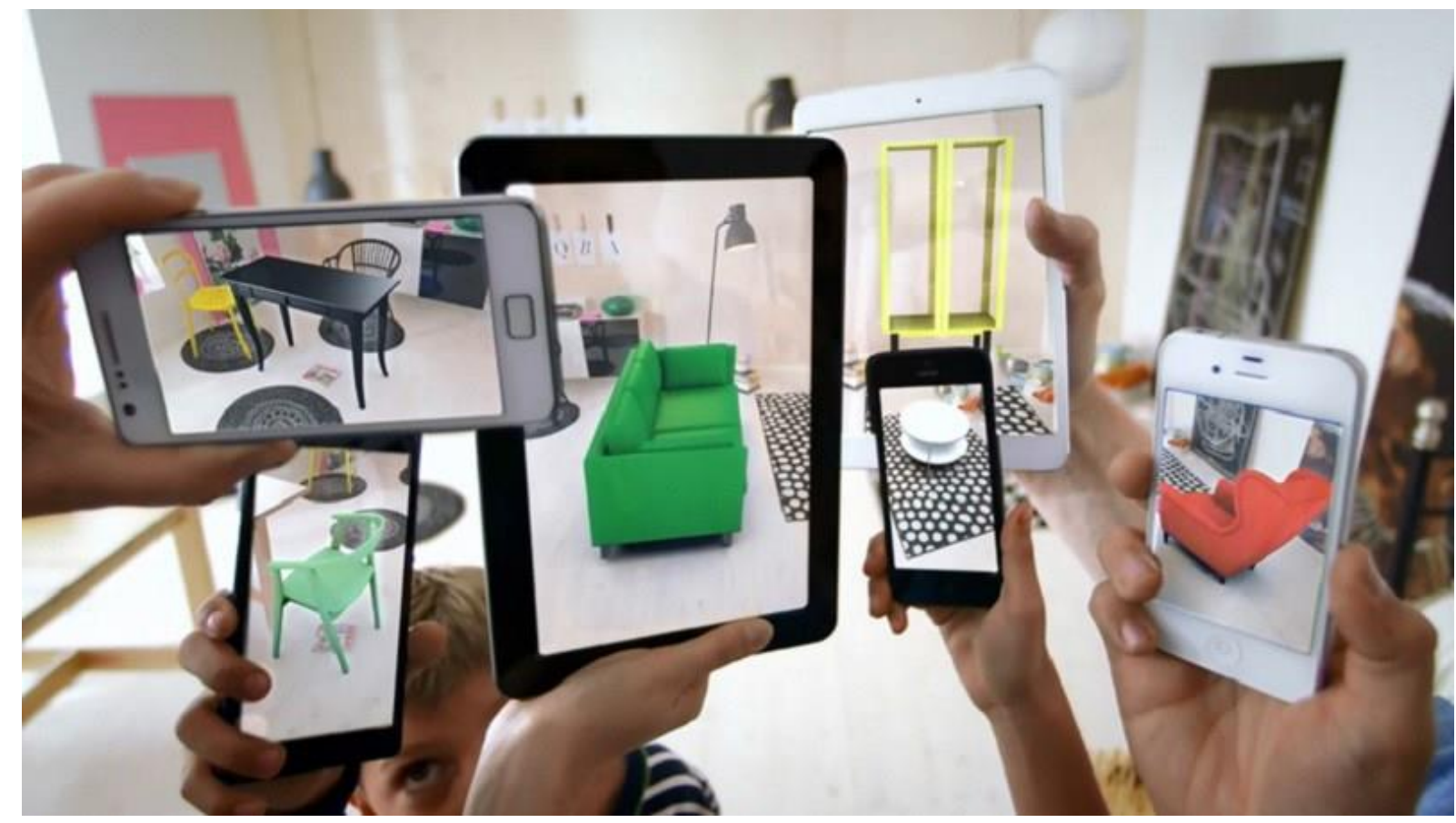

Picture 4. IKEA Place Application

Reference: https://www.log.com.tr/ikeanin-artirilmis-gerceklik-uygulamasi-yayinda-video/

This application is designed for consumers to shop quickly and securely and it's an important indicator that augmented reality technology can be used without glasses. But in addition to all these positive aspects this application increases the consumer's consumption rate and allows the consumer to consume anytime. In this context, it's observed that the application encourages consuming more than consumer needs. Discount advantages and low paid shipping options which are offered by IKEA specific to the application both help reduce its storage expenses and cause the customers to consume continuously without changing their location. 


\begin{tabular}{|c|c|c|c|}
\hline Visua & Denotation & Connotation & Virtual Meaning \\
\hline & $\begin{array}{l}\text { There is an } \\
\text { armchair image in } \\
\text { the smart phone. } \\
\text { An armchair } \\
\text { which is not } \\
\text { really there can be } \\
\text { seen in the screen } \\
\text { of a smart phone. } \\
\text { The armchair and } \\
\text { the wall are in the } \\
\text { same color and } \\
\text { have different } \\
\text { shades. }\end{array}$ & $\begin{array}{l}\text { The user wanted to see an } \\
\text { armchair, which does not } \\
\text { exist in the real } \\
\text { ambiance, in the screen } \\
\text { of a smart phone. She/he } \\
\text { is evaluating the } \\
\text { appropriateness of the } \\
\text { armchair, which has } \\
\text { sharp lines, to the real } \\
\text { ambiance. }\end{array}$ & $\begin{array}{l}\text { The armchair, } \\
\text { which is not found } \\
\text { in the real } \\
\text { ambiance, can be } \\
\text { seen as digitally } \\
\text { coded and in real } \\
\text { color with real } \\
\text { dimensions. }\end{array}$ \\
\hline & $\begin{array}{l}\text { An image of a } \\
\text { tree in front of a } \\
\text { white colored } \\
\text { wall is seen in the } \\
\text { smart phone. A } \\
\text { tree which does } \\
\text { not exist in real } \\
\text { ambiance is seen } \\
\text { in the screen of a } \\
\text { smart phone. The } \\
\text { tree and the wall } \\
\text { are in different } \\
\text { shades. }\end{array}$ & $\begin{array}{l}\text { The user wanted to see a } \\
\text { tree, which does not exist } \\
\text { in the real ambiance, in } \\
\text { the screen of a smart } \\
\text { phone. The tree is } \\
\text { decorated for the new } \\
\text { year and is being } \\
\text { evaluated whether it is } \\
\text { appropriate for the real } \\
\text { ambiance or not. The } \\
\text { color of the tree and the } \\
\text { ambiance are in } \\
\text { harmony. }\end{array}$ & $\begin{array}{l}\text { A new year's tree, } \\
\text { which does not } \\
\text { exist in real } \\
\text { ambiance, is seen } \\
\text { as digitally coded, } \\
\text { in real dimensions, } \\
\text { colors, and has } \\
\text { decorations like a } \\
\text { real tree. }\end{array}$ \\
\hline & $\begin{array}{l}\text { An image of a } \\
\text { footstool in front } \\
\text { of a white colored } \\
\text { wall is seen in the } \\
\text { smart phone. A } \\
\text { footstool which } \\
\text { does not exist in } \\
\text { real ambiance is } \\
\text { seen in the screen } \\
\text { of a smart phone. } \\
\text { The color of the } \\
\text { footstool and the } \\
\text { ambiance are in } \\
\text { harmony. }\end{array}$ & $\begin{array}{l}\text { The user wanted to see a } \\
\text { footstool, which does not } \\
\text { exist in the real } \\
\text { ambiance, in the screen } \\
\text { of a smart phone. The } \\
\text { user is checking if the } \\
\text { footstool is appropriate to } \\
\text { the real ambiance. The } \\
\text { color of the footstool and } \\
\text { the ambiance are in } \\
\text { harmony. }\end{array}$ & $\begin{array}{l}\text { A footstool, which } \\
\text { does not exist in } \\
\text { real ambiance, is } \\
\text { seen as digitally } \\
\text { coded, in real } \\
\text { dimensions, } \\
\text { colors, and has } \\
\text { decorations like a } \\
\text { real tree. }\end{array}$ \\
\hline
\end{tabular}




\begin{tabular}{|c|c|c|c|}
\hline 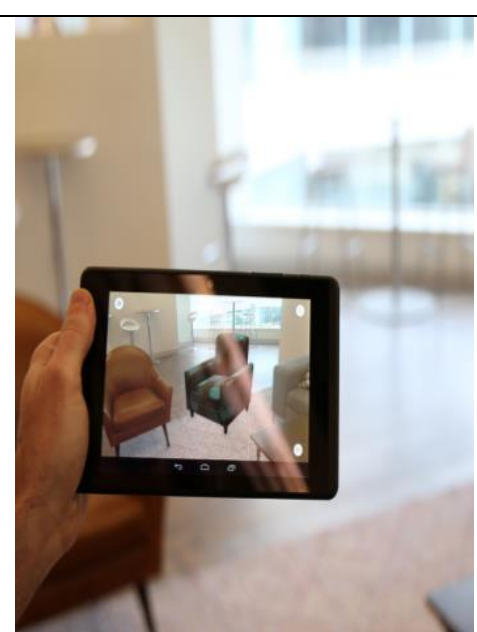 & $\begin{array}{l}\text { There is an image } \\
\text { of a black } \\
\text { armchair in front } \\
\text { of a light colored } \\
\text { shade is seen in } \\
\text { the tablet. An } \\
\text { armchair which is } \\
\text { not really there } \\
\text { can be seen in the } \\
\text { screen of a tablet. } \\
\text { The colors of the } \\
\text { armchair and the } \\
\text { ambiance contrast } \\
\text { each other. }\end{array}$ & $\begin{array}{l}\text { The user wanted to see a } \\
\text { black armchair, which } \\
\text { does not exist in the real } \\
\text { ambiance, in the screen } \\
\text { of a tablet. The } \\
\text { appropriateness of the } \\
\text { armchair to the ambiance } \\
\text { is being checked. The } \\
\text { color of the armchair and } \\
\text { the ambiance are not in } \\
\text { harmony. }\end{array}$ & $\begin{array}{l}\text { A black armchair, } \\
\text { which is not found } \\
\text { in the real } \\
\text { ambiance, is seen } \\
\text { as digitally coded } \\
\text { and in real color } \\
\text { with real } \\
\text { dimensions. }\end{array}$ \\
\hline E & $\begin{array}{l}\text { There is a blue } \\
\text { armchair image in } \\
\text { front of a blue } \\
\text { wall in the screen } \\
\text { of a smart phone. } \\
\text { An armchair } \\
\text { which is not } \\
\text { really there can be } \\
\text { seen in the screen } \\
\text { of a smart phone. } \\
\text { The armchair and } \\
\text { the wall are in the } \\
\text { same color and } \\
\text { have different } \\
\text { shades. }\end{array}$ & $\begin{array}{l}\text { The user wanted to see a } \\
\text { blue armchair, which } \\
\text { does not exist in the real } \\
\text { ambiance, in the screen } \\
\text { of a smart phone. She/he } \\
\text { is evaluating the } \\
\text { appropriateness of the } \\
\text { armchair to the real } \\
\text { ambiance. The armchair } \\
\text { and the wall are in the } \\
\text { same color and have } \\
\text { different shades. They } \\
\text { are in harmony. }\end{array}$ & $\begin{array}{l}\text { A blue armchair, } \\
\text { which is not found } \\
\text { in the real } \\
\text { ambiance, is seen } \\
\text { as digitally coded } \\
\text { and in real color } \\
\text { with } \\
\text { dimensions. real }\end{array}$ \\
\hline 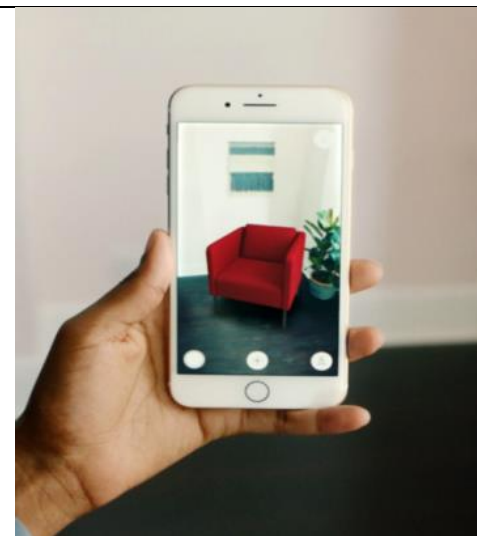 & $\begin{array}{l}\text { An image of a red } \\
\text { armchair in front } \\
\text { of a white colored } \\
\text { wall is seen in the } \\
\text { smart phone. An } \\
\text { armchair which is } \\
\text { not really there } \\
\text { can be seen in the } \\
\text { screen of a smart } \\
\text { phone. }\end{array}$ & $\begin{array}{l}\text { The user wanted to see a } \\
\text { red armchair, which does } \\
\text { not exist in the real } \\
\text { ambiance, in the screen } \\
\text { of a smart phone. The } \\
\text { appropriateness of the } \\
\text { armchair to the ambiance } \\
\text { is being checked. The } \\
\text { color of the armchair and } \\
\text { the ambiance are } \\
\text { different but they are in } \\
\text { harmony. }\end{array}$ & $\begin{array}{l}\text { A red armchair, } \\
\text { which is not found } \\
\text { in the real } \\
\text { ambiance, is seen } \\
\text { as digitally coded } \\
\text { and in real color } \\
\text { with real } \\
\text { dimensions. }\end{array}$ \\
\hline
\end{tabular}




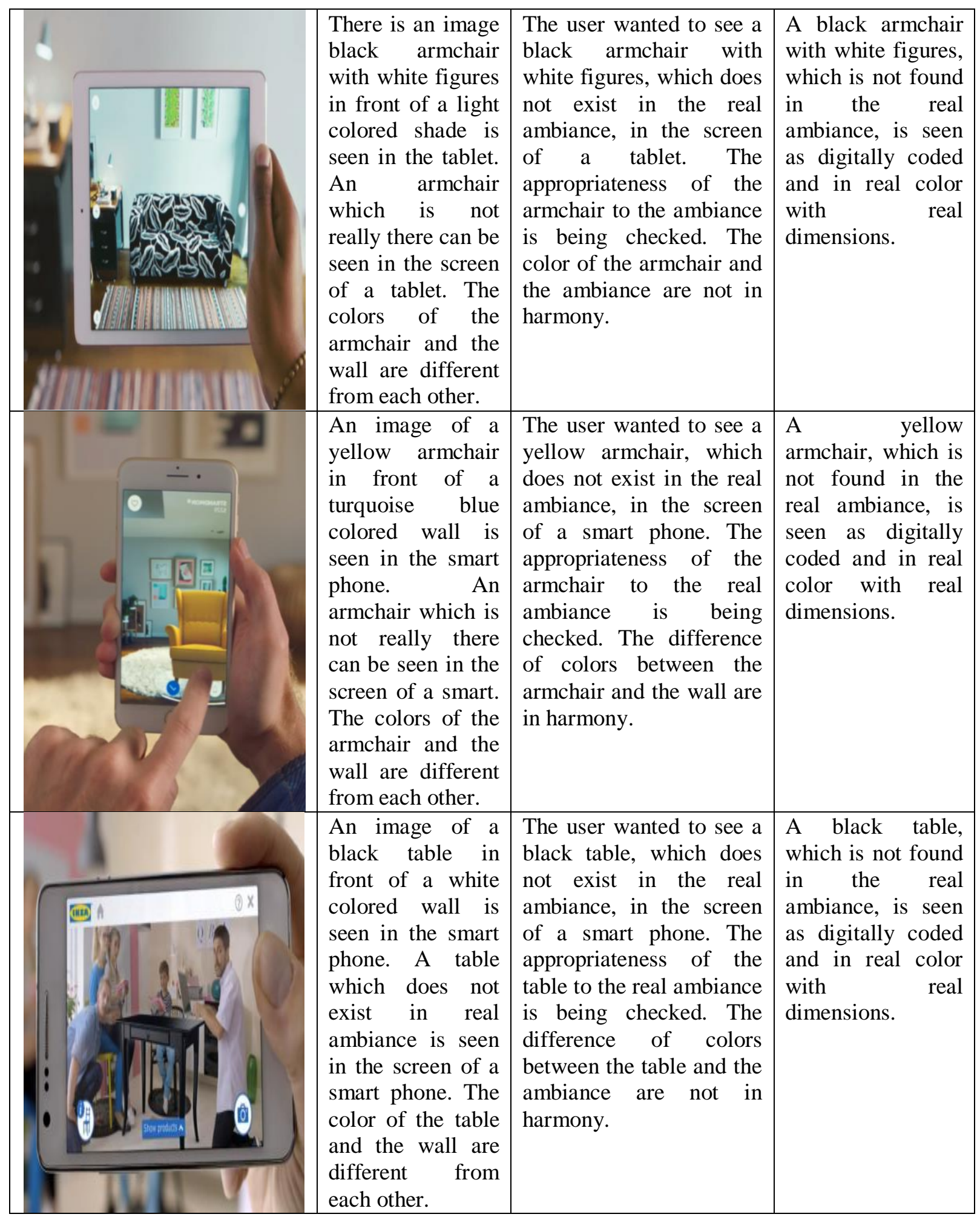




\begin{tabular}{|c|c|c|c|}
\hline$\frac{48 \mathrm{~d}}{0}$ & $\begin{array}{l}\text { An image of a } \\
\text { blue chair in front } \\
\text { of a dark blue } \\
\text { colored wall is } \\
\text { seen in the smart } \\
\text { phone. A chair } \\
\text { which does not } \\
\text { exist in real } \\
\text { ambiance is seen } \\
\text { in the screen of a } \\
\text { smart phone. The } \\
\text { color of the chair } \\
\text { and the wall are in } \\
\text { same color but in } \\
\text { different shades. }\end{array}$ & $\begin{array}{l}\text { The user wanted to see a } \\
\text { blue chair, which does } \\
\text { not exist in the real } \\
\text { ambiance, in the screen } \\
\text { of a smart phone. The } \\
\text { appropriateness of the } \\
\text { chair to the real ambiance } \\
\text { is being checked. The } \\
\text { color of the chair and the } \\
\text { ambiance are in } \\
\text { harmony. }\end{array}$ & $\begin{array}{l}\text { A blue chair, } \\
\text { which is not found } \\
\text { in the real } \\
\text { ambiance, is seen } \\
\text { as digitally coded } \\
\text { and in real color } \\
\text { with real } \\
\text { dimensions. }\end{array}$ \\
\hline
\end{tabular}

\section{CONCLUSION}

The development level of the countries is stated with the knowledge of the societies and there are significant changes in the process of transition from industrial society to information based informatics society. Informatics is a branch of science which examines the systems required for collection, classification, storage, processing, transmission and use of information also researches and practices technology. The most important point is that technology is for the society and informatics is for science. Informatics makes our lives easier by establishing the bridge between the information world and the technology world. Consumers and producers in social media support communication channels via various platforms like Facebook, Twitter, MySpace (Ortaç \& Akçay, 2016: 179).

Information based technology innovations brought in by the informatics society eliminate the space and time in the communication process. Thanks to rapid circulation of information, the data received by individuals is increasing day by day. In the informatics society in which we face information bombardment, the new communication environments are the areas where interaction increases mostly. The channel component in the communication process of new communication environments is transforming with technological developments. Especially with the interaction which is the most important feature of the communication process, communication environments are being digitized. Classical communication environments turn into digital environments and continue transmitting information in new communication environments. At this point the qualities of the communication environments which are expressed as new and transformation of the notions with these qualifications stand as an important subject.

As Chayko mentions passive consumers have turned into active consumers and they have become consumers who also produce and they are called prosumers (2018: 78). The transition of analog to digital requires some specifications. The so called new environments are based on digital. There is an increase in the interaction with the digital component. Interactivity which is one of the most important features of the communication process also shows progress. In this context in all fields a transformation occurs. The transformation process is expressed as Digital/Electronic Transformation. With this transformation, the concept of classical games is replaced by digital games as a new communication environment. Game is a life laboratory. For children game means transferring their worries, anxieties, and happiness; in games which make more meaningful connections between the dream world and the real world, by passing through the game's filter the child can better recognize surroundings which is full of uncertainty; the life and his/her own self. With this feature, games become important communication environments.

Increasing population rate, variable economic conditions and difficult work conditions are exhausting individuals. Individuals try many different ways to relax. The most easily accessible of these is television. "The sense of being there" or "the sense of being instant" has always been very important in order to attract a wide audience for traditional TV broadcasting (Karadağ, 2017b: 724). In front of 
television, individuals get rid of their daily anger with the violence scenes shown on television. Live broadcast from the scene which was once in the monopoly of traditional media has turned out to be a broadcast opportunity which is now open to access of a more wide range population, with the help of digital technology. Furthermore, with applications that make live broadcast possible from a mobile with a single touch; this possibility is now in the hands of everyone who has a mobile phone (Karadağ, 2017a: 88).Digital games, which are now considered as leisure time activity, are taking the place of television.

In today's world digital play can be the best example given for nowadays communication. Digital games are individual communication tools. Variety of digital plays are sold in stores and consumed by users. There are many different reasons why digital games are popular. The main reason of this is individual's not having their target levels or qualifications. In search of different things, the individual satisfies this missing point via digital games. Digital games are preferred new communication devices because of limitless features they serve.

The show presents itself as a huge peremptory which cannot be discussed and reached. "The thing we see is good, good thing can be seen" (Debord 2006). In the end, the show means nothing else then a desire for sleep, a nightmare of a chained modern society. With the new communication technologies our private lives come to an end. When a society has turned into a surveillance society, it means it has lost the promoter dynamics of the dominant classes and cannot be ruled by natural ways. At this point, science and technology, which are the means of freedom in revolutionary capitalism, have turned into the tools of destruction in the rotten capitalism. As a result of individuals doing their work distant and easily by using technological innovations, the bodies are getting lost. With this lost, the subject of the individual is replaced by the object of him/her (Yengin \& Kınay, 2016: 351-379).

Social media is a virtual projection of the real society. According to this, the public in the digital space does the natural voting in social media medium like in real life society. But in social media public opinion formation happens faster than the real life. In this context, the definition of the public opinion research which takes place in real life society and has "a sample used for generalization to a lower group or bigger group or the function of collecting objective data in a systematic, scientific and unbiased way from the population which the sample is taken" (Lake \& Harper, 2008: 5) is also acceptable in social media research (Yengin \& Bayrak, 2017: 381).

\section{REFERENCES}

Akyazl, Ayşenur. (2017). "Social Media As A New Platform In Corporate Communicatilon: A Comparative Analysis Of Public And Foundation Universities In Istanbul", Researches on Science and Art in 21st Century Turkey, Gece Publishing, Ed: Hasan Arapgirlioglu, Atilla Atık, Rubert L. Williott, Edward Turgeon, 1485-1496.

Baldini, Massimo. (2000). "İletişim Tarihi”, Çev: Gül Batus, İstanbul, Avcıol Basımevi.

Baudrillard, Jean. (2005). "Simülakrlar ve Simülasyon”, Ankara, Doğu Batı Yayınları.

Chayko, Mary. (2018). "Süperbağ(lanti)ll: Internet, Dijital Medya \& Tekno-Sosyal Hayat" (Çevirmenler: Berkan Bayındır, Deniz Yengin ve tamer Bayrak) İstanbul: Der Yayınlarl.

Fiske, John. (2014). "İletişim Çalışmalarına Giriş" (Çev: Süleyman Irvan). Ankara: Pharmakon Yayınevi.

Güngör, Nazife. (2011). “Illetişim, Kuram ve Yaklaşımlar”, Ankara: Siyasal Kitabevi.

Karadăg, Gökmen Hakan. (2017a). "Reporting and Interviewing Styles of Professional and Citizen Reporters on Periscope", Communication and Technology Congress-CTC2017, 22-23 November 2017, İstanbul Aydin University, 88-104. DOI: 10.7456/ctc_2017_07.

Karadăg, Gökmen Hakan. (2017b). "What Does Periscope Offer To Professional And Citizen Reporters? A Sample Study From Turkey", The Turkish Online Journal of Design, Art and Communication-TOJDAC, 7(4), 709-727. DOI: 10.7456/10704100/016.

King, Brett. (2016). "Augmented", MediaCat, İstanbul.

Laughey, Dan. (2007). "Key Themes in Media Theory”, New York: Open University Press. 
Lister, Martin., Dovey, Jon., ve Diğerleri. (2009). "New Media: A Critical Introduction”, London: Routledge.

Lyon, David. (2006). “Günlük Hayatı Kontrol Etmek: Gözetlenen Toplum”, Istanbul, Kalkedon Yayinlart.

Lyon, David. (1998). "The Information Society: Issues and Illisions", Malden, Polity Press.

Manovich, Lev. (2001). "The Language of New Media", Cambridge, The MIT Press.

Mcluhan, Marshall. (1964). "Understanding Media”, NY, Mcgrawhill.

Ortaç, F. Rlfat \& Akçay, Deniz. "Taxation of Social Media Advertisements", Marmara Üniversitesi Öneri Dergisi, Cilt 12 Sayl 45, Ocak 2016, ISSN: 1300-0845, ss. 175-185. (DOI: 10.14783/od.v12i45.1000020009)

Scoble, Robert. \& Israel, Shel. (2017). "The Fourth Transformation”, US, Patrick Brewster.

Turkle, S. (2011). Alone Together. New York: Basic Books.

Uçak, Olcay. (2015). "Yeni Medyanın Yazılı ve Görsel İletilerde Kullandiğı Gerçek Üstü Kodlar İle Oyun Gerçek Kavramlarındaki Anlam Dönüşümü”, 1. Ulusal Medya ve Haber Sempozyumu 2015, 21 23 Ekim 2015, İstanbul Aydin Üniversitesi, 97-118.

Webster, Frank. (2006). "Theories of The Information Society”, New York, Routledge.

Yengin, Deniz. (2014). "Yeni Medya ve Dokunmatik Toplum”, Derin Yayınlarl, İstanbul.

Yengin, Deniz. (2015). "Yeni Medyanin Olanaklart: Semantik Web”, The Turkish Online Journal of Design, Art and Communication-TOJDAC, 5(1), 44-53. DOI: 10.7456/10501100/004.

Yengin, Deniz. (2017). "Illetişim Çalışmalarında Araştırma Yöntemleri ve Uygulamaları", Der Yayınlarl, İstanbul.

Yengin, Deniz \& Bayrak, Tamer (2018). "Sanal Gerçeklik", Der Yayınları, İstanbul.

Yengin, Deniz. (2017). "Virtual Reality as Technology", Communication and Technology CongressCTC2017, 22-23 November 2017, Istanbul Aydin University, 57-68. DOI: 10.7456/ctc_2017_05.

Yengin, Deniz \& Bayrak, Tamer (2017). "Public Opinion In Social Media", The Turkish Online Journal of Design, Art and Communication-TOJDAC, 7(2), 376-386. DOI: 10.7456/10702100/019.

Yengin, Deniz \& Kinay, Ömür (2016). "Transformation of Leisure Time in New Media: Binge Watch", The Turkish Online Journal of Design, Art and Communication-TOJDAC, 6(4), 351-379. DOI: $10.7456 / 10604100 / 001$. 